\title{
POMNIKI HISTORII - SPOJRZENIE KRYTYCZNE
}

\section{DĄBROWSKI Jacek ${ }^{1}$}

\section{${ }^{1}$ Jacek Dąbrowski, Polski Komitet Ochrony Dziedzictwa Przemysłowego TICCIH} https://orcid.org/0000-0002-2146-976X

ABSTRAKT: Pomnik historii jako pojęcie pojawiło się w Ustawie $z$ dnia 15 lutego 1962 r. o ochronie dóbr kultury i o muzeach. W obecnym akcie prawnym: Ustawie $z$ dnia 23 lipca 2003 r. o ochronie zabytków i opiece nad zabytkami pomnik historii jest formą ochrony zabytków. Od 1962 r. nie wprowadzono żadnych zasad obejmujących kryteria wyboru zabytków oraz sposoby przygotowywania i procedowania wniosków o uznanie za pomnik historii. Powoduje to, że uznawanie zabytków nieruchomych za pomniki historii jest obarczone dużą uznaniowością. Lista obejmująca 105 pomników historii nie jest reprezentatywna ani ilościowo, ani jakościowo w stosunku do całego zasobu zabytków wpisanych do rejestru zabytków. Konieczne jest wprowadzenie przepisów regulujących ten stan, a także jasne zasady finansowania prac konserwatorskich zabytków uznanych za pomniki historii.

SŁOWA KLUCZE: Pomnik Historii, ochrona zabytków, prawo ochrony zabytków

Określenie „Pomnik Historii” pojawiło się w polskim prawodawstwie ochrony zabytków w Ustawie $z$ dnia 15 lutego 1962 r. o ochronie dóbr kultury i o muzeach ${ }^{1}$. W myśl art. 6 ust. 1 tej ustawy przyjęto, że: Zabytki nieruchome o szczególnej wartości dla kultury narodowej moga być na wniosek Ministra Kultury i Sztuki uznane przez Radę Państwa za pomniki historii. Ustanowienie „pomników historii” było związane z realizacją ratyfikowanej przez Polskę Konwencji o ochronie dóbr kulturalnych $w$ razie konfliktu zbrojnego, podpisanej w Hadze $w$ dniu 14 maja $1954 r^{2}{ }^{2}$ i wprowadzonego przez nią Międzynarodowego Rejestru Dóbr Kulturalnych Objętych Ochroną Specjalną (art. 18 ust. 6 Konwencji). W ust. 3 przywołanego artykułu Minister Kultury i Sztuki otrzymał zadanie wydania rozporządzenia regulującego organizację i sposób ochrony „pomników historii”.

Pierwsze oceny Ustawy o ochronie dóbr kultury i o muzeach pojawiły się po około 10 latach jej funkcjonowania. 
Władysław Sieroszewski - ówczesny konsultant prawny w Zarządzie Muzeów i Ochrony Zabytków, w tekście opublikowanym w „Ochronie Zabytków”, zawarł następującą ocenę uregulowań dotyczących pomników historii: Każdego, kto rozumie znaczenie naszej spuścizny kulturalnej musi przykro uderzyć fakt, że w ciagu blisko 10 lat ani jeden $z$ czołowych polskich zespołów zabytkowych nie został uznany za pomnik historii. Stworzenie tego pojęcia uważaliśmy stusznie za duże osiągnięcie polskiej myśli konserwatorskiej. Ma ona znaczenie prekursorskie, gdyż obecnie UNESCO, przystępując do opracowania konwencji o ochronie dóbr kultury o znaczeniu ogólnoludzkim, podejmuje analogiczną koncepcje.

Jeżeli jednak dotąd „pomniki historii” nie weszly w stadium realizacji, stało się to skutkiem samej dyspozycji art. 6. Artykuł ten bowiem w 2 ustępie nakazuje zgłaszać pomniki historii do Międzynarodowego Rejestru Dóbr Kultury pod Ochrona Specjalną. Otóż wpis do tego rejestru jest obwarowany nie tylko zastrzeżeniem, że obiekt nie może stużýc celom wojskowym, ale także, iż nie może być położony w pobliżu lotnisk, zakładów przemysłowych pracujacych dla produkcji wojennej, a nawet dworców kolejowych, mostów i arterii o znaczeniu strategicznym. W tych warunkach ani Wawel, ani Łazienki i Wilanów, Malbork, Główne Miasto w Gdańsku, czy wiele innych czołowych świadectw naszej kultury nie moga być wpisane do tego rejestru [...].

Tak więc przepis, który miał na celu podniesienie rangi pomników historii, przyczynia się w praktyce do uniemożliwienia ich realizacji.

Oprócz analizy przyczyn braku działań na rzecz ustanowienia pomników historii, W. Sieroszewski sformułował wnioski de lege ferenda dotyczące kwestii sprawowania ochrony pomników historii: [...] Ponadto jeżeli chcemy poddać pomniki historii specjalnemu reżimowi, np. wyłaczyć je spod kompetencji wojewódzkich konserwatorów zabytków, to koncepcja taka powinna znaleźć swe odbicie w Ustawie. Na podstawie powyższych rozważań proponujemy skreślić dotychczasową treść art. 6 ust. 2 i 3 i na jego miejsce wstawić:

„2. Ochrone pomnika historii sprawuje konserwator pomnika historii powołany przez Ministra Kultury i Sztuki, który w stosunku do tego pomnika ma uprawnienia wojewódzkiego konserwatora zabytków. Może być powołany jeden wspólny konserwator dla dwóch lub więcej pomników historii.

3. Szczegółowy zakres czynności konserwatora pomnika historii oraz zasady i organizację ochrony tego pomnika określa statut nadany przez Ministra Kultury i Sztuki”s.

Podobnie negatywną ocenę dla niewykorzystania przepisów art. 6 wyraził prof. Kazimierz Malinowski: [...] artykuł 6 dopuszczający nazwanie niektórych obiektów „pomnikami kultury”. Autorom chodzito o to, aby wyróżnić takie obiekty jak Wawel, Wilanów, a nawet Malbork czy Oświęcim i nadać im specjalny status, otworzyć możliwości powołania odrębnego konserwatora itd. Ponadto chodziło o to, aby do tej kategorii zaliczyć wszystkie obiekty, które będa zgłoszone do Międzynarodowego Rejestru Dóbr Kulturalnych Objętych Ochroną Specjalna (Konwencja Haska). Ponieważ do wysłania listy takich obiektów nie doszło i nikt nie starał się, aby uzyskać ten tytuł - to

W. Sieroszewski (1971). Czy ustawa o ochronie dóbr kultury i o muzeach dojrzała do nowelizacji: artykut dyskusyjny, Ochrona Zabytków, nr 3, s. 163-172.

4 Ibidem, s. 164.

5 Ibidem, s. 164-165. 
piękne zamierzenie pozostało martwa litera prawa ${ }^{6}$.

Ten stan prawny, oceniany krytycznie w odniesieniu do Pomników Historii, trwał w sposób niezmieniony aż do 1990 r., kiedy to na podstawieUstawy z dnia 19 lipca 1990 r. o zmianie ustawy o ochronie dóbr kultury i o muzeach ${ }^{7}$, dokonano korekty wynikającej z faktu ratyfikowania przez Polskę Konwencji w sprawie ochrony światowego dziedzictwa kulturalnego i naturalnego, przyjętej w Paryżu w dniu 16 listopada 1972 r. ${ }^{8}$ W art. 6 ust. 1 Radę Państwa zastąpił Prezydent RP, zaś w ust. 2 tego samego artykułu, Międzynarodowy Rejestr Dóbr Kultury Objętych Ochroną Specjalną został zastąpiony przez Komitet Dziedzictwa Światowego w celu wpisania na „Listę dziedzictwa światowego" i objęcia ich [PH] ochroną na podstawie Konwencji w sprawie ochrony światowego dziedzictwa kulturalnego i naturalnego. Na marginesie warto dodać, że owe zmiany nastąpiły 14 lat po ratyfikowaniu Konwencji przez Polskę...

Na podstawie przepisu art. 6 ust. 3 Ustawy o ochronie dóbr kultury i o muzeach na Ministra Kultury nałożony został obowiązek wydania rozporządzenia regulującego organizację i sposób ochrony pomników historii. Minister Kultury nigdy tego zadania jednak nie wypełnił...

Pierwsze Pomniki Historii ustanowione zostały dopiero w 1994 r., czyli 32 lata po uchwaleniu Ustawy o ochronie dóbr kultury i o muzeach. Na mocy Rozporządzeń Prezydenta RP pomnikami historii zostało wówczas 15 obiektów i obszarów zabytkowych. Wśród nich znalazły się wpisane już wcześniej na Listę Światowego Dziedzictwa: kopalnia soli w Wieliczce (1978), historyczny zespół miasta w Krakowie (1978), historyczny zespół miasta w Warszawie (1980), historyczny zespół miasta w Zamościu (1992) oraz wpisane na Listę Światowego Dziedzictwa trzy lata później (1997): zespół zamku krzyżackiego w Malborku i zespół staromiejski w Toruniu.

Potem, aż do 2003 r., kiedy to weszła w życie nowa Ustawa o ochronie zabytków i opiece nad zabytkami znowu mamy do czynienia ze swoistą „zapaścią” pomników historii. Wyjątkiem był rok 2000, kiedy za PH uznano zespół manierystycznego parku pielgrzymkowego w Kalwarii Zebrzydowskiej oraz kopalnię soli w Bochni. Ale i w tym przypadku związane to było z wpisaniem Kalwarii Zebrzydowskiej rok wcześniej na Listę Światowego Dziedzictwa i zamierzeniem poszerzenia wpisu kopalni soli w Wieliczce o kopalnię soli w Bochni, co ostatecznie zostało sfinalizowane w $2013 \mathrm{r}$.

Dalsze poszerzanie liczby obiektów i obszarów zabytkowych obdarzonych mianem Pomników Historii, odbywało się pod rządami nowych przepisów o ochronie zabytków. Na ich podstawie - art. 15 Ustawy o ochronie zabytków i opiece nad zabytkami, pomnik historii stał się nową formą ochrony zabytków - można więc uznać, że w ten sposób ustawodawca chciał podnieść ich rangę. Szczegółowe uregulowania odnośnie pomników historii umieszczono w art. 15. Na ich podstawie:

1. Prezydent Rzeczypospolitej Polskiej, na wniosek ministra właściwego do spraw kultury i ochrony dziedzictwa narodowego, w drodze rozporządzenia, może uznać za pomnik historii zabytek

K. Malinowski (1973). Dziesięciolecie Ustawy o Ochronie Dóbr Kultury i o Muzeach, Ochrona Zabytków, nr 2, s. 87.

Dz.U. z 1990 r Nr 56, poz. 322.

Dz.U. z 1976 r. Nr 32, poz. 190 i 191. 


\section{Jacek Dabrowski}

nieruchomy wpisany do rejestru lub park kulturowy o szczególnej wartości dla kultury, określając jego granice.

2. Minister [...] może złożyć wniosek, o którym mowa w ust. 1, po uzyskaniu opinii Rady Ochrony Zabytków. [...]

4. Minister [...] może przedstawić Komitetowi Dziedzictwa Światowego wniosek o wpis pomnika historii na "Listę dziedzictwa światowego" w celu objęcia tego pomnika ochrona na podstawie Konwencji $w$ sprawie ochrony światowego dziedzictwa kulturalnego $i$ naturalnego, przyjętej $w$ Paryżu [...].

W znacznym stopniu przepisy te były - z pewnymi „unowocześnieniami” - powtórzeniem przepisów art. 6 Ustawy o ochronie dóbr kultury i o muzeach. Przy tym, ustawodawca uznał za zbędne jakiekolwiek dodatkowe uregulowania odnośnie zasad ustanawiania pomników historii czy sposobów ich ochrony, zapewne ze względu na to, że pomniki historii jako forma ochrony zabytków są chronione poprzez inne formy ochrony zabytków (!). Bowiem zgodnie z treścią przywołanego art. 15 ust. 1 pomnikiem historii mogą być wyłącznie zabytki wpisane do rejestru zabytków lub będące parkiem kulturowym. Można więc uznać, że ustawodawca przyjął założenie, że pomniki historii mają być (pomimo uznania ich za formę ochrony zabytków) jedynie „honorowym tytułem” podkreślającym prestiż i wagę zabytku, nie niosącym za sobą żadnych praw i obowiązków.

Z przepisu art. 15 ust. 2 wynika, że minister właściwy do spraw kultury i ochrony dziedzictwa narodowego może złożyć wniosek do Prezydenta RP o uznanie zabytku nieruchomego za pomnik historii. Dla wypełnienia luki, jaką jest niewątpliwie brak przepisów wykonawczych regulujących kwestie kryteriów wyboru obiektów mających być pomnikami historii oraz sposobów przygotowania, procedowania i oceny wniosku, na polecenie Ministerstwa Kultury i Dziedzictwa Narodowego, Krajowy Ośrodek Badań i Dokumentacji Zabytków (ob. Narodowy Instytut Dziedzictwa) przygotował Kryteria i procedury uznawania za pomnik historii, które następnie przyjęła i zaakceptowała Rada Ochrony Zabytków9.

Potwierdzono w tym dokumencie, że pomnikhistorii choćjest formąochrony zabytków, to przede wszystkim „jest szczególną formą nobilitacji” i „trudnym i niezwykłym uprzywilejowaniem"10, choć wszelkie rygory ochrony biorą się stąd, że zabytki te są chronione poprzez inne formy ochrony zabytków.

Zgodnie z przyjętymi - choć zupełnie nieformalnymi kryteriami - pomniki historii mają być zabytkami nieruchomymi o znaczeniu ponadregionalnym, o dużych wartościach historycznych, naukowych $i$ artystycznych, majacymi znaczenie dla polskiego dziedzictwa kulturalnego, utrwalonymi w świadomości społecznej i stanowiącymi źródło inspiracji dla kolejnych pokoleń. Ponadto musza to być zabytki, które:

- $\quad$ zachowaly pierwotna kompozycję przestrzenna lub uległy nieznacznym przekształceniom,

\footnotetext{
https://www.nid.pl/pl/Dla_wlascicieli_i_zarzadcow/opieka-nad-zabytkami/pomniki-historii/prawa-iobowiazki/ - dostęp 12.08.2019 r.

10 https://www.nid.pl/pl/Dla_wlascicieli_i_zarzadcow/opieka-nad-zabytkami/pomniki-historii/kryteriawyboru/ - dostęp 12.08.2019 r.
} 
- $\quad$ sa jednorodne stylowo lub o czytelnych i zharmonizowanych ze soba nawarstwieniach, - $\quad$ sa należycie wyeksponowane w przestrzeni miejskiej lub krajobrazie i zachowały pierwotne relacje $z$ otoczeniem,

- $\quad$ sa dziełami wybitnych twórców, np.: architektów, planistów, architektów krajobrazu, ogrodników,

- $\quad$ sa dobrze zachowane lub w stanie pozwalającym na ich rewaloryzacje,

- $\quad$ sa przedmiotem troski konserwatorskiej ${ }^{11}$.

W szczególności - zgodnie z przyjętymi kryteriami - pomnikami historii moga być: krajobrazy kulturowe, układy urbanistyczne, ruralistyczne i zespoły budowlane, dzieła architektury $i$ budownictwa lub zespoly tych dzieł o wspólnych cechach stylowych, użytkowych lub konstrukcyjnych, dzieła budownictwa obronnego, obiekty dziedzictwa przemystowego, inżynierii lądowej i wodnej, parki i ogrody, cmentarze, miejsca upamiętniające wydarzenia historyczne bądź związane $z$ działalnościa wybitnych osobistości lub instytucji oraz zabytki archeologiczne ${ }^{12}$.

Kryteria zostały zakreślone na tyle szeroko, że mogą obejmować prawie wszystkie zabytki nieruchome (np. opozycyjne kryteria: tradycyjne lub unikalne). Ograniczeniem są - na szczęście - zastrzeżenia, iż pomniki historii mają mieć znaczenie ponadregionalne, mają mieć wysokie wartości ustawowe, tj. znaczenie historyczne, naukowe i artystyczne, mają mieć - co ważne - znaczenie dla polskiego dziedzictwa kulturalnego, mają trwać w świadomości społecznej i inspirować kolejne pokolenia. Gdyby nie one pomnikiem historii mógłby zostać w zasadzie każdy zabytek nieruchomy.

W procedurach „regulujących” proces ustanawiania pomników historii pojawił się zapis nie mający żadnego umocowania w prawie - postulowany przez Radę Ochrony Zabytków - wymóg uchwalenia miejscowego planu zagospodarowania przestrzennego dla obszarów (np. miejskie założenia historyczne) zabytkowych pretendujących do miana pomnika historii. Kolejnym nie mającym żadnej podstawy prawnej jest zapis, jaki ma się pojawić w regulaminie Programu MKiDN Ochrona zabytków, zobowiązujący zarządców pomników historii ubiegających się o dotację do posiadania Planu zarządzania - na wzór miejsc wpisanych na Listę Światowego Dziedzictwa. W ten sposób zarządcy lub właściciele pomników historii zostaną obciążeni nowym, pozaustawowym obowiązkiem.

Analizując proces ustanawiania pomników historii trudno oprzeć się wrażeniu, że są one najbardziej „upolitycznioną” formą ochrony zabytków. Zgłaszanie kolejnych kandydatur do miana pomnika historii ma swoje źródło głównie w inicjatywach władz samorządowych lub kościelnych, dążących do nadania „wyższej, honorowej” rangi swojemu zabytkowi oraz wspieraniu tych inicjatyw przez różnorodne środowiska polityczne. Niestety najmniej daje się dostrzec $\mathrm{w}$ tym procesie planową politykę konserwatorską kreowaną i realizowaną na najwyższym szczeblu. Jedynie pomniki historii ustanawiane w latach 2017-2019 wynikają wprost z inicjatywy ministerstwa - zgodnie z przepisami Ustawy o ochronie zabytków i opiece

\footnotetext{
11 Ibidem.

12 Ibidem.
} 
nad zabytkami, jedynie minister właściwy do spraw kultury i ochrony dziedzictwa narodowego jest uprawniony do składania wniosków o ustanowienie pomnika historii. To - czy mają one reprezentatywny charakter wobec całego zasobu zabytkowego i na ile wynikało to z przyjętej długofalowej polityki konserwatorskiej jest już zupełnie inną kwestią.

Konsekwencją jest wysoce problematyczna reprezentatywność pomników historii wobec całego zasobu zabytkowego (wpisanego do rejestru zabytków i będącego parkami kulturowymi).

W momencie powstawania niniejszego tekstu mamy w naszym kraju 105 pomników historii, co stanowi ok. 0,13\% zabytków wpisanych do rejestru zabytków. Najliczniej reprezentowaną kategorią zabytków wśród pomników historii są obiekty i zespoły sakralne, należące w ogromnej większości do kościoła rzymskokatolickiego - jest ich $46^{13}$, co daje prawie $44 \%$ wszystkich $\mathrm{PH}$, podczas gdy wszystkie obiekty sakralne $\mathrm{w}$ rejestrze zabytków stanowią $16 \%$. Jedynie pojedyncze obiekty sakralne uznane za pomniki historii należą do innych wyznań - np. dwie świątynie ewangelicko-augsburskie (Kościoły Pokoju w Jaworze i Świdnicy) czy dwa meczety wraz z mizarami w Kruszynianach i Bohonikach. Ciekawostką jest to, że wśród uznanych za pomnik historii rzymskokatolickich obiektów sakralnych znalazło się aż 13 benedyktyńskich i cysterskich zespołów klasztornych. Choć jak dotąd uznania wśród konserwatorów nie znalazły wybitne założenia klasztorne SS. Benedyktynek w Staniątkach i Żarnowcu.

Istotną - choć z pewnością jeszcze nie zamkniętą grupą wśród pomników historii są historyczne założenia miejskie - obecnie jest ich 18 (ponad 17\% wszystkich PH). Jednym z kolejnych kandydatów mogłoby być np. miasto Gniew na Pomorzu. Jest to miasto lokowane na prawie chełmińskim w 1297 r. charakteryzujące się w pełni zachowanym układem przestrzennym, z reliktami średniowiecznych murów obronnych, XIV-wiecznym kościołem św. Marcina, zachowaną w ogromnym stopniu historyczną zabudową oraz monumentalnym krzyżackim zamkiem.

O swego rodzaju „nadreprezentacji” można mówić w stosunku do zabytków techniki, obiektów inżynieryjnych czy przemysłowych. Obecnie aż 13 tego typu obiektów i zespołów zostało uznanych za pomniki historii, co daje imponująca proporcję wynoszącą $12,3 \%$, podczas gdy w rejestrze zabytków jest ich zaledwie ok. 4,5\%. A warto tu także wymienić dwa, ściśle związane $\mathrm{z}$ rozwojem przemysłu zespoły mieszkaniowej zabudowy robotniczej - Katowice-Nikiszowiec i Żyrardów. Biorąc pod uwagę ogólną niechęć środowisk konserwatorskich do tej - uznawanej za „brudną" - kategorii zabytków, taka ich liczba w gronie najbardziej prestiżowych polskich zabytków napawa optymizmem.

Analiza rozkładu terytorialnego pomników historii jasno pokazuje dążenie do równomiernego „nasycenia” województw tą formą ochrony zabytków. Nie ma to oczywiście nic wspólnego z rzeczywistym rozkładem ilościowym i jakościowym zabytków chronionych wpisami do rejestru zabytków. Ale dzięki temu miejscem najbogatszym w „prestiżowe” zabytki jest miasto Gdańsk, w którym znajduje się już 5, w pełni zasłużonych pomników historii (prawie 4\%

${ }^{13}$ W tej liczbie ujęte są zarówno obiekty i zespoły sakralne uznane indywidualnie za pomniki historii, jak również te, które są wymienioną w nazwie częścią pomnika historii. Np. katedra w Kielcach (razem z dawnym pałacem biskupów) czy zespół katedralny w Katowicach (razem z gmachem Województwa i Sejmu Śląskiego). 
wszystkich PH). Należą do nich: Miasto w zasięgu obwarowań z XVII wieku, zespół pocysterskokatedralny w Oliwie, pole bitwy na Westerplatte, Twierdza Wisłoujście i Stocznia Gdańska.

Najbardziej specyficzną kategorią pośród pomników historii są trzy pola bitew: pod Grunwaldem w 1410 r., pod Racławicami w 1894 r. oraz na Westerplatte w 1939 r. Lista ta mogłaby być z pewnością dłuższa, a wśród propozycji nie mogłoby zabraknąć miejsca wyjątkowego zwycięstwa oręża polskiego - jedynej zwycięskiej bitwy morskiej pod Oliwą z 26 listopada $1627 \mathrm{r}$.

\section{Wnioski}

Regulacje dotyczące pomników historii funkcjonują w polskim prawie ochrony zabytków od 1962 r. - zarówno w Ustawie z 15 lutego 1962 roku o ochronie dóbr kultury i o muzeach, jak i w Ustawie $z$ dnia 23 lipca 2003 roku o ochronie zabytków i opiece nad zabytkami. Pomnik historii - w założeniach ustawodawców - miał wyróżniać te spośród zabytków nieruchomych, które mają „szczególną wartość dla kultury”. Nigdy nie przyjęto jakichkolwiek przepisów wykonawczych, które regulowałyby kryteria i sposób ustanawiania pomników historii oraz zasady ich ochrony. Upoważnienie do wydania stosownego rozporządzenia na podstawie przepisów ustawy o ochronie dóbr kultury i o muzeach miał Minister Kultury i Sztuki, jednak nigdy z niego nie skorzystał. W ustawie o ochronie zabytków i opiece nad zabytkami już takiej delegacji zabrakło. W zamian pomniki historii „podniesiono” do rangi formy ochrony zabytków, w sposób tak kuriozalny, że ich ochrona wynikają z tego, że są chronione poprzez inne formy ochrony zabytków (!).

Skoro więc nie ma żadnych kryteriów wyboru oraz zasad przygotowania i procedowania wniosków o uznanie za pomnik historii, utworzone zostały swego rodzaju pozaprawne narzędzia, jakimi są wytyczne i zalecenia opracowane przez Krajowy Ośrodek Badań i Dokumentacji Zabytków (obecnie Narodowy Instytut Dziedzictwa), a zaakceptowane i rekomendowane przez Radę Ochrony Zabytków. Pomimo tego, że nie mają żadnej podstawy prawnej są stosowane do dziś.

Rozszerzanie listy zabytków uznanych za pomniki historii nie opiera się na dobrze zaplanowanej polityce konserwatorskiej, wypracowanej wspólnie przez administrację konserwatorską przy udziale środowisk konserwatorskich i naukowych. Jest to efekt - za wyjątkiem (jak wspomniano wcześniej) lat 2017-2019 - inicjatyw przede wszystkim środowisk samorządowych i kościelnych przy wsparciu środowisk konserwatorskich.

Sporym niebezpieczeństwem dla przyszłych pomników historii mogą być zapisy procedowanego obecnie projektu Strategii Rozwoju Kapitału Społecznego 2030 ${ }^{14}$. W dokumencie umieszczono zapis: Zwiększenie liczby Pomników Historii w regionach słabszych ekonomicznie powinno przynieść rozwój turystyki kulturowej, a w konsekwencji stworzyć warunki do szybszego niż do tej pory zmniejszania wskaźnika bezrobocia, większej zamożności mieszkańców i przezwyciężenia

14 http://bip.mkidn.gov.pl/pages/posts/ogloszenie-konsultacji-publicznych-projektu-uchwaly-rady-ministrow-2998.php. 
negatywnych tendencji migracyjnych, zarówno na poziomie regionalnym, jak i również w obrębie poszczególnych województw.

Jak wynika z powyższego tekstu, podstawowym kryterium ustanawiania pomników historii nie miałyby być ich wartości kulturowe, a ich „przydatność. w rozwoju ekonomicznym regionów i hamowaniu procesów migracyjnych. Przyjęcie takiego sposobu postępowania przyczyniłoby się z pewnością do degradacji obecnego prestiżu pomników historii.

Brak jasnych zasad, opartych o konkretne przepisy prawne, powoduje dużą uznaniowość w typowaniu zabytków do uznania za pomniki historii i częstym stosowaniu zasady „kto pierwszy ten lepszy".

Sytuacji nie poprawia także brak poszanowania obecnie obowiązujących przepisów, które jednoznacznie określają drogę postępowania: najpierw rejestr zabytków lub park kulturowy, potem uznanie za pomnik historii, a w końcu ewentualny wniosek o wpis na Listę Światowego Dziedzictwa. Odstępstwem od tej zasady określonej w ustawie o ochronie zabytków i opiece nad zabytkami są przypadki m.in. Kościołów Pokoju w Jaworze i Świdnicy, które najpierw - w 2001 roku - zostały wpisane na Listę Światowego Dziedzictwa, a dopiero 15 marca 2017 r. zostały uznane za pomniki historii, czy Stoczni Gdańskiej, której część (Stocznia Cesarska) została wpisana do rejestru zabytków w 2017 r., następnie 10 grudnia 2018 r. została uznana za pomnik historii ${ }^{15}$, by w końcu we wniosku z 2019 r. zostać zgłoszoną do wpisu na Listę Światowego Dziedzictwa. Tyle, że wniosek o wpis na tę listę dotyczy znacznie większego obszaru, którego znaczna część nie tylko nie jest jeszcze pomnikiem historii, ale także nie jest objęta wpisem do rejestru zabytków.

Pomniki Historii na trwale wpisały się w krajobraz polskiej ochrony zabytków, choć nie wynikają z planowej polityki ochrony zabytków, a raczej ze sporej przypadkowości. Konieczne jest jednak - dla ugruntowania uznanej już, wysokiej rangi pomników historii - opracowanie i wdrożenie - najlepiej w formie rozporządzenia Ministra Kultury i Dziedzictwa Narodowego jasno określonych kryteriów wyboru, sposobu przygotowywania i procedowania wniosków oraz roli różnych podmiotów w tym procesie. Uregulowania, a właściwie ustanowienia, wymagają także zasady ochrony pomników historii. Tu powinno znaleźć się miejsce m.in. na postulowany przez Radę Ochrony Zabytków obowiązek uchwalania miejscowych planów zagospodarowania przestrzennego dla obszarów zabytkowych już będących i planowanych jako pomniki historii, a także konieczność opracowywania planów zarządzania, jako jednego z narzędzi polityki konserwatorskiej.

Nowe przepisy powinny obejmować także wprowadzenie, postulowanego przez różne środowiska, systemu finansowania pomników historii. System finansowania winien obejmować w pierwszej kolejności prace konserwatorskie przy zabytkach będących pomnikami historii, a także proces dostosowywania istniejących pomników historii do nowych wymogów (mpzp oraz plany zarządzania) i wsparcie w przygotowywaniu nowych wniosków.

${ }_{15}$ W granicach pomnika historii znalazły się: Stocznia Cesarska, Sala BHP oraz Plac Solidarności z Pomnikiem Poległych Stoczniowców Grudnia 1970 r. 
Konieczne jest także dokonanie weryfikacji ustanowionych już pomników historii pod kątem prawidłowości wyznaczenia granic czy zgodności treści zarządzenia z załącznikami graficznymi. Przykładem może być pomnik historii Gniezno - katedra p.w. Wniebowzięcia NMP $i s ́ w$. Wojciecha. Granica zespołu zabytkowego, wyznaczona na załączniku graficznym obejmuje wyłącznie katedrę wraz z najbliższym otoczeniem. Zaś granice określone w $₫ 3$ ust. 1 zarządzenia, obejmują całą działkę nr 50 o powierzchni 5,4 ha (czyli katedrę, kościół św. Jerzego, siedzibę Muzeum i Archiwum Archidiecezjalnego oraz ogrody), co potwierdza analiza danych katastralnych na portalu geoportal.pl, z tym, że tam działka ma numer 50/1.

Jesteśmy zobowiązani, aby podjąć wszelkie niezbędne działania, aby pomniki historii w końcu rzeczywiście - pod każdym względem - stały się elitarną kategorią lub formą ochrony zabytków. 


\section{Bibliografia}

Frączak K., Skuteczność ochrony pomników historii w prawie polskim [w:] Prawo ochrony zabytków, red. K. Zeidler, Warszawa-Gdańsk 2014.

Malinowski K., Dziesięciolecie Ustawy o Ochronie Dóbr Kultury i o Muzeach, Ochrona Zabytków 1973, nr 2, s. 85-88.

Mechanizmy prawne zarzadzania dziedzictwem kultury, pod. red. A. Jagielskiej-Burduk, Gdańsk-Warszawa 2016.

Pruszyński J., Dziedzictwo kultury Polski. Jego straty i ochrona prawna, t. I-II, Kraków 2001.

Raport na temat funkcjonowania systemu ochrony dziedzictwa kulturowego w Polsce po roku 1989, red. J. Purchla, Kraków 2008.

Sieroszewski W., Czy ustawa o ochronie dóbr kultury i o muzeach dojrzała do nowelizacji: artykut dyskusyjny, Ochrona Zabytków 1971, nr 3, s. 163-172.

Sieroszewski W., Ochrona prawna dóbr kultury w Polsce, Warszawa 1971.

Ustawa z dnia 15 lutego 1962 r. o ochronie dóbr kultury Dz.U. z 1999 r. Nr 98, poz. 1150 z późn. zm.

Ustawa z dnia 23 lipca 2003 r. o ochronie zabytków i opiece nad zabytkami - Dz.U. z 2018 r. poz. 2087 z późn. zm.

Zalasińska K., Prawna ochrona zabytków nieruchomych w Polsce, Warszawa 2010. 